\title{
Polychlorinated dibenzo-p-dioxins and dibenzofurans in water and six fish species from Dongting Lake, China
}

\author{
Lirong Gao*, Qin Zhang, Bing Zhang, Wenbin Liu, Ke Xiao \\ State Key Laboratory of Environmental Chemistry and Ecotoxicology, Research Center for Eco-Environmental Science, Chinese Academy of Sciences, P.O. Box 2871, \\ Beijing 100085, China
}

\section{H I G H L I G H T S}

- The PCDD/Fs concentrations in eight water samples from Dongting Lake were determined.

- PCDD/Fs concentrations were above that allowed by the US EPA.

- 2,3,7,8-Chlorinated PCDD/F concentration differed in six fish species.

- The bioaccumulation of PCDD/F congeners cannot solely be explained by their physical-chemical properties.

\section{A R T I C L E I N F O}

\section{Article history:}

Received 11 October 2013

Received in revised form 11 April 2014

Accepted 13 April 2014

Available online 14 May 2014

Handling Editor: J. de Boer

\section{Keywords:}

Polychlorinated dibenzo-p-dioxins and

dibenzofurans

Water

Fish

Dongting Lake

\begin{abstract}
A B S T R A C T
There have been few studies of polychlorinated dibenzo- $p$-dioxins and dibenzofurans (PCDD/Fs) in environmental water because of the large volume of water required for PCDD/Fs analysis. Water quality directly affects aquatic organisms, and little is known about how PCDD/Fs are transported in aquatic environments. PCDD/Fs were analyzed in eight water samples from Dongting Lake, China, which was contaminated with PCDD/Fs because of sodium pentachlorophenate use between the 1960s and the 1980s. The total PCDD/F concentrations in the samples were $36-345 \mathrm{pg} \mathrm{L}^{-1}$, and the mean was $191 \mathrm{pg} \mathrm{L}^{-1}$. Octachlorodibenzo-p-dioxin was the most abundant PCDD/F congener in every sample, contributing $67-95 \%$ of the total 2,3,7,8-chlorinated PCDD/F concentrations. The toxic equivalent (WHO-TEQ) concentrations in the samples were $0.17-0.37 \mathrm{pg} \mathrm{L}^{-1}$, and the mean was $0.28 \mathrm{pg} \mathrm{L}^{-1}$, which is higher than the Canadian environmental quality guideline $\left(0.038 \mathrm{pg} \mathrm{L}^{-1}\right.$ WHO-TEQ for freshwater $)$ and the United States Environmental Protection Agency water quality criterion (0.014 $\mathrm{pg} \mathrm{L}^{-1}$ WHO-TEQ). PCDD/Fs were also determined in six fish species collected from Dongting Lake, to assess the concentrations, accumulation patterns, and potential for toxic effects. The total 2,3,7,8-chlorinated PCDD/F concentrations in the fish samples were $2.2-17.9 \mathrm{gg} \mathrm{g}^{-1}$ (wet weight), and the dominant congeners were octachlorodibenzo- $p$-dioxin, 1,2,3,4,6,7,8-heptachlorodibenzo-p-dioxin, 1,2,3,4,7,8-hexachlorodibenzop-dioxin, and 2,3,4,7,8-pentachlorodibenzofuran. The PCDD/F WHO-TEQs were 0.10-0.92 ww (3.3$65.3 \mathrm{lw}) \mathrm{pg} \mathrm{g}^{-1}$ in different species of fish. PCDD/F congener patterns in fish may be affected by food chain biomagnification and the lipid content of the species.
\end{abstract}

(c) 2014 Elsevier Ltd. All rights reserved.

\section{Introduction}

Polychlorinated dibenzo-p-dioxins and dibenzofurans (PCDD/ Fs) are stable and persistent hydrophobic organic chemicals that are widespread in the environment and can be biomagnified through the food chain. Many studies have shown that PCDD/Fs are found in a range of environmental media, including air, water, soil, sediment, animals, and humans (Kumar et al., 2001; Im et al.,

\footnotetext{
* Corresponding author. Tel.: +86 1062849356 .

E-mail address: gaolr@rcees.ac.cn (L. Gao).
}

2004; Shaq et al., 2009). Their physical and chemical properties mean that PCDD/Fs bioaccumulate in aquatic biota, and this is of increasing concern.

Lake, river, and marine sediments have often been studied because they can show historical PCDD/F accumulation trends (Yeager et al., 2007; Ren et al., 2009; Josefsson et al., 2012). In contrast, there have been few studies of PCDD/Fs in environmental water because of the large volume of water that is needed for PCDD/F analysis. However, the concentrations of PCDD/Fs in water bodies are of great interest because the main human exposure pathway is through the food chain, and fish and other organisms 
that humans eat bioaccumulate PCDD/Fs. Aquatic organisms are exposed to PCDD/Fs from the water itself and from their food, and it is not clearly understood which organisms predominantly bioaccumulate PCDD/Fs from their food and which organisms predominantly bioaccumulate them from the water. It is also important to understand the distribution of PCDD/Fs between the sediment, water, and biota in aquatic systems to determine the origin of the PCDD/Fs and to develop appropriate source control strategies. The accumulation of different PCDD/F congener in an environmental compartment will be different because each congener has different physical and chemical properties.

Dongting Lake, which has a very large surface area $\left(2691 \mathrm{~km}^{2}\right)$, is in southern China, and is the second largest freshwater lake in China. Dongting Lake plays an important role in regulating the amount of water in the Yangtze River. Asian schistosomiasis has been endemic in the Dongting Lake region for centuries, and has a devastating effect on the health of the local population. Technical sodium pentachlorophenate (Na-PCP) has been sprayed in the Dongting Lake area since the 1960s, to control the spread of snail-borne schistosomiasis. PCDD/Fs are by-products of Na-PCP (Bao et al., 1995), and may, therefore, have entered the environment in this area, leading to human exposure. It has been prohibited to spray Na-PCP in the Dongting Lake area since the 1990s, but $\mathrm{PCDD} / \mathrm{Fs}$ are chemically inert and can remain in the environment for many years. Sediments from Dongting Lake have been shown to be heavily polluted with PCDD/Fs (Zheng et al., 1997). Dongting Lake is, therefore, a good ecosystem for studying the transfer of PCDD/Fs to organisms and humans in the field, and the health impacts of PCDD/Fs.

In this paper, we present the concentrations and patterns of PCDD/Fs in water and six fish species collected from Dongting Lake. The absolute concentrations, relative concentrations (congener profiles), and the 2,3,7,8-tetrachlorodibenzo-p-dioxin (toxic) equivalents (TEQs) were measured/calculated and used to assess the possible sources of PCDD/Fs and the potential for toxic effects caused by PCDD/Fs. The aims of the study also were to assess PCDD/Fs bioaccumulation in different fish species according to the feeding habits of the fish (graminivores, piscivores, or predators).

\section{Material and methods}

\subsection{Sampling}

Eight water samples were taken from each of eight locations (Fig. 1), distributed over Dongting Lake, in March 2004. The sample sites are included as national or provincial key monitoring areas, and are used to assess lake pollution. Each site was identified using a global positioning system. The sampling site descriptions are shown in Fig. 1. Triplicate water samples were collected at three of the sites, and one set of triplicate fish samples was collected. Water samples of $20 \mathrm{~L}$ were collected using a stainless steel bucket, and put in brown glass bottles. The sample bottles were returned to the laboratory within a few hours of the samples being taken, then stored in a refrigerator until the pretreatment was started. In the laboratory, each $20 \mathrm{~L}$ sample was filtered through a glass microfiber filter (GF/C, $47 \mathrm{~mm}$ diameter; Whatman, Maidstone, UK) to separate the PCDD/Fs in the suspended solid and dissolved phases. The residue trapped on the filter contained PCDD/Fs in the suspended particle phase and the filtrate contained PCDD/Fs in the dissolved phase. The filtrate was then passed through a chromatography column containing XAD-2 resin, on which the PCDD/Fs in the dissolved phase were trapped.

Fish were caught in Dongting Lake in March 2004, wrapped in aluminum foil, and stored at $-20^{\circ} \mathrm{C}$ until analysis. The names and biological parameters of the fish were shown in Table 1 . The XAD-2 resin, filter and fish were analyzed within one month after arrived in the laboratory.

\subsection{Analytical method}

The XAD-2 resin together with the filter was extracted (in a preextracted extraction thimble) with 50\% dichloromethane in hexane for $24 \mathrm{~h}$, in a Soxhlet apparatus. The crude extract was purified using, sequentially, an acidified silica gel column, a multilayer silica gel column, and a basic alumina column (described below).

Fish samples were analyzed as soon as they reached the laboratory. Each fish sample (fish muscle with skin attached) was homogenized and freeze-dried, ${ }^{13} \mathrm{C}$-labeled surrogate standards added

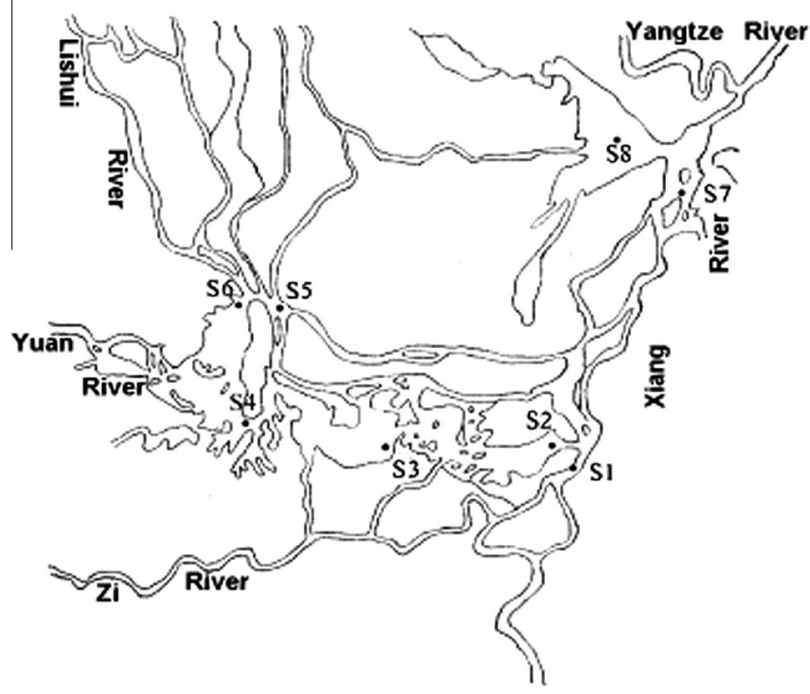

\begin{tabular}{cl}
\hline Somple site & Geographic position \\
\hline S1 & $28^{\circ} 49^{\prime} 50 \mathrm{~N}, 112^{\prime} 52^{\prime} 57 \mathrm{E}$ \\
\hline S2 & $28^{\circ} 57^{\prime} 08 \mathrm{~N}, 112^{\circ} 52^{\prime} 03 \mathrm{E}$ \\
\hline S3 & $28^{\circ} 49^{\prime} 03 \mathrm{~N}, 112^{\prime} 24^{\prime} 39 \mathrm{E}$ \\
\hline S4 & $28^{\circ} 51^{\prime} 04 \mathrm{~N}, 112^{\prime} 18^{\prime} 33 \mathrm{E}$ \\
\hline S5 & $29^{\circ} 03^{\prime} 33 \mathrm{~N}, 112^{\prime} 19^{\prime} 03 \mathrm{E}$ \\
\hline S6 & $29^{\circ} 03^{\prime} 40 \mathrm{~N}, 112^{\prime} 17^{\prime} 47 \mathrm{E}$ \\
\hline S7 & $29^{\circ} 20^{\prime} 14 \mathrm{~N}, 113^{\circ} 03^{\prime} 46 \mathrm{E}$ \\
\hline S8 & $29^{\prime} 21^{\prime} 37 \mathrm{~N}, 113^{\circ} 03^{\prime} 42 \mathrm{E}$ \\
\hline
\end{tabular}

Fig. 1. Water sampling locations (marked S1-S8) in Dongting Lake, China. 
Table 1

The names and biological parameters of the fish that were sampled.

\begin{tabular}{llll}
\hline English name & Latin name & Age (Year) & Length $(\mathrm{cm})$ \\
\hline Bream & Cypriniformes & $3-4$ & $42-50$ \\
Carp & Cyprinus carpio & $4-5$ & $35-38$ \\
Yellow catfish & Pelteobagrus eupogon & $4-5$ & $14-18$ \\
Pomfret & Pampus sinensis & $3-4$ & $19-21$ \\
Mandarin fish & Siniperca chuatsi & $3-4$ & $19-23$ \\
Catfish & Silurus asotus & $5-6$ & $50-54$ \\
\hline
\end{tabular}

(following US EPA method 1613B), and mixed with anhydrous sodium sulfate (baked at $660^{\circ} \mathrm{C}$ ). This mixture was extracted (in a pre-extracted thimble) with $50 \%$ dichloromethane in hexane for $24 \mathrm{~h}$, in a Soxhlet apparatus. The crude extract was concentrated to about $5 \mathrm{~mL}$ using a rotary evaporator, then dried under a stream of nitrogen until it reached a constant weight. The lipid content in the sample was calculated by dividing the dry extract residue weight by the wet weight of the sample. The residue was then redissolved and purified using, sequentially, an acidified silica gel column, a multilayer silica gel column, and a basic alumina column (described below).

The acidified silica gel column used for the extract purification was a glass column (15 mm i.d.) containing $10 \mathrm{~g}$ of silica gel containing $44 \%(\mathrm{w} / \mathrm{w})$ sulfuric acid, topped with a thin layer of sodium sulfate. This column was cleaned with $50 \mathrm{~mL}$ hexane, the sample extract added, and then eluted with $70 \mathrm{~mL}$ hexane. The extract was then rotary evaporated to $1 \mathrm{~mL}$. The multilayer silica gel column ( $15 \mathrm{~mm}$ i.d.) was packed with (from the bottom) $1 \mathrm{~g}$ of silica gel, $2 \mathrm{~g}$ of silica gel treated with $10 \%(\mathrm{w} / \mathrm{w}) \mathrm{AgNO}_{3}, 1 \mathrm{~g}$ of silica gel, $8 \mathrm{~g}$ of silica gel containing $44 \%(\mathrm{w} / \mathrm{w})$ sulfuric acid, $1 \mathrm{~g}$ of silica gel, $5 \mathrm{~g}$ of silica gel containing 33\% (w/w) $1 \mathrm{M} \mathrm{KOH}, 1 \mathrm{~g}$ of silica gel, and a thin layer of sodium sulfate. The column was cleaned with $70 \mathrm{~mL}$ hexane, the sample extract added, and then eluted with $100 \mathrm{~mL}$ hexane. The extract was then rotary evaporated to $1 \mathrm{~mL}$. The basic alumina column ( $10 \mathrm{~mm}$ i.d.) was packed with $8 \mathrm{~g}$ of basic alumina and topped with a thin layer of sodium sulfate. The column was cleaned with $100 \mathrm{~mL}$ hexane, the sample extract added, and then eluted with $100 \mathrm{~mL} 5 \%$ dichloromethane in hexane, and then $50 \mathrm{~mL} \mathrm{50 \%} \mathrm{dichloromethane} \mathrm{in} \mathrm{hexane.} \mathrm{The} \mathrm{50 \%} \mathrm{dichloromethane}$ in hexane fraction was rotary evaporated to around $500 \mu \mathrm{L}$, then evaporated to $50 \mu \mathrm{L}$ under a gentle nitrogen stream. Finally, internal standards $\left({ }^{13} \mathrm{C}_{12}\right.$-labeled PCDD/Fs; Cambridge Isotope Laboratories, Andover, MA, USA) were added before instrumental analysis. The $\mathrm{PCDD} / \mathrm{F}$ congeners were analyzed using an Agilent 6890 gas chromatograph (Agilent Technologies, Santa Clara, CA, USA) coupled to an Autospec Ultima mass spectrometer (Waters, Milford, MA, USA). The mass spectrometer was operated in electron impact mode, at $35 \mathrm{eV}$, with a trap current of $600 \mu \mathrm{A}$. The mass spectrometry parameters and quality control procedures used were as described in US EPA method 1613B. The gas chromatograph was equipped with a CTC PAL autosampler, (CTC Analytics AG, Switzerland) which was used to inject $1 \mu \mathrm{L}$ of each sample into the splitless injector. Separation was achieved using a DB-5MS fused silica capillary column (60 m long, $250 \mu \mathrm{m}$ i.d., $0.25 \mu \mathrm{m}$ film thickness; J\&W, Agilent Technologies), using helium as the carrier gas at a constant flow rate of $1.2 \mathrm{~mL} \mathrm{~min}^{-1}$. The oven temperature program was $160^{\circ} \mathrm{C}$, which was held for $2 \mathrm{~min}$, increased at $7.5^{\circ} \mathrm{C} \mathrm{min}-1$ to $220^{\circ} \mathrm{C}$, which was held for $16 \mathrm{~min}$, increased at $5^{\circ} \mathrm{C} \mathrm{min}^{-1}$ to $235^{\circ} \mathrm{C}$, which was held for $7 \mathrm{~min}$, increased at $5^{\circ} \mathrm{C} \mathrm{min}-1$ to $330^{\circ} \mathrm{C}$, which was held for $1 \mathrm{~min}$. The quantitative determination was performed using an isotope dilution method. The acceptance criteria were that the chlorine isotope ratio was within $\pm 15 \%$ of the theoretical ratio, the retention time was within $2 \mathrm{~s}$ of the standard retention time, and the peak response was at least three times the background noise level.

\subsection{Quality assurance and quality control}

Several steps were taken to assure that the data collected in this study are of high quality including collection of field and lab blanks, triplicates water and fish samples from collocated samplers and breakthrough samples. Field and laboratory blanks were taken with each set of samples and processed in an identical manner to the samples. The method detection limit (MDL) is determined by the background amounts on these blanks rather than the instrumental detection limit. None of the lower chlorinated congeners were detected in the blanks. OCCD was the most prevalent congener in the blanks. However, their concentrations in the blanks corresponded to less than $8 \%$ of the concentrations found in the samples. Concentrations of triplicates obtained at the collocated sites were in good agreement with each other. Among the 17 2,3,7,8-PCDD/Fs congeners, 2,3,7,8-TCDD was the most difficult to measure because the concentrations are extremely low. Recoveries of each chemical during clean-up procedure were calculated separately from surrogates and were also determined, which ranged from $51 \%$ to $116 \%$, indicating that the sample preparation (extraction and cleanup) worked properly for all of the samples. Our laboratory participated in an international inter-calibration study from 2003 to 2011, the results of which demonstrated that the performance of our method was quite acceptable for the analysis of PCDD/Fs.

\section{Results and discussion}

\section{1. $P C D D / F s$ in water}

The PCDD/Fs concentrations found in the water samples from Dongting Lake are shown in Table 2. The detection limits were different for different samples and different congeners, typically being $0.02-0.2 \mathrm{pg} \mathrm{L}^{-1}$ for individual congeners. The total $\mathrm{PCDD} / \mathrm{F}$ ( $\Sigma \mathrm{PCDD} / \mathrm{F}$ ) concentrations were $36-345 \mathrm{pg} \mathrm{L}^{-1}$, and the mean was $191 \mathrm{pg} \mathrm{L}^{-1}$. The highest total 2,3,7,8-chlorinated $\mathrm{PCDD} / \mathrm{F}$ $(\Sigma 2,3,7,8-\mathrm{PCDD} / \mathrm{F})$ concentration $\left(110 \mathrm{pg} \mathrm{L}^{-1}\right)$ was found at site $\mathrm{S} 2$, and the lowest concentration $\left(17 \mathrm{pg} \mathrm{L}^{-1}\right)$ was found at sites S3 and S5. $\Sigma 2,3,7,8-\mathrm{PCDD} / \mathrm{F}$ concentrations of $135-5329 \mathrm{pg} \mathrm{g}^{-1}$ with a mean of $2218 \mathrm{pg} \mathrm{g}^{-1}$, have been reported in sediment samples (Gao et al., 2008). The highest $\Sigma$ PCDD/F concentration in sediment was found at location S1, and the lowest concentration was found at location S5. The highest and lowest $\Sigma$ PCDD/F concentrations in the water samples, therefore, matched the highest and lowest $\Sigma \mathrm{PCDD} / \mathrm{F}$ concentrations in the sediments. In this study, the suspended particles were not filtered from the water, the $\mathrm{PCDD} / \mathrm{F}$ concentrations in water maybe also influenced by suspended particle concentration. In a previously published paper (Li et al., 2011), the suspended particle concentration in Dongting Lake was found to be $141.08 \pm 31.46 \mathrm{mg} \mathrm{L}^{-1}$, and the average water temperature during the sampling period was found to be $10.1^{\circ} \mathrm{C}$. Liu et al. (2008) determined PCDD/F concentrations in water, suspended particulate matter (SPM), and water + SPM samples from the Xijiang River, and they calculated the water/water + SPM concentration ratios for different $\mathrm{PCDD} / \mathrm{F}$ congeners and homolog groups. We can roughly estimate the ratios of PCDD/F concentrations in the water to suspended particles were $3.9-65.4 \%$ in the water samples of this study.

It can be seen from Table 2 that octachlorodibenzo-p-dioxin (OCDD) was the dominant PCDD/F congener in the water from every site, contributing $67-95 \%$ of the $\Sigma 2,3,7,8-\mathrm{PCDD} / \mathrm{F}$ concentrations. Bao et al. (1995) reported that OCDD contributed 76\% to the 
Table 2

PCDD/F concentrations ( $\mathrm{pg} \mathrm{L}^{-1}$ ) in the water samples collected from Dongting Lake.

\begin{tabular}{|c|c|c|c|c|c|c|c|c|}
\hline \multicolumn{9}{|l|}{ Sample site } \\
\hline & S1 & S2 & S3 & S4 & S5 & S6 & S7 & S8 \\
\hline $2,3,7,8-\mathrm{TeCDF}$ & $<0.07$ & 0.1 & $<0.09$ & $<0.07$ & $<0.04$ & 0.03 & $<0.2$ & $<0.05$ \\
\hline $1,2,3,7,8-\mathrm{PeCDF}$ & $<0.1$ & $<0.06$ & $<0.06$ & $<0.07$ & $<0.05$ & $<0.05$ & $<0.2$ & $<0.05$ \\
\hline $2,3,4,7,8-\mathrm{PeCDF}$ & 0.2 & 0.1 & $<0.05$ & 0.04 & $<0.05$ & $<0.05$ & $<0.1$ & 0.03 \\
\hline $1,2,3,4,7,8-\mathrm{HxCDF}$ & 0.3 & 0.2 & 0.1 & $<0.03$ & 0.03 & 0.02 & 0.3 & 0.1 \\
\hline $1,2,3,6,7,8-\mathrm{HxCDF}$ & 0.4 & 0.3 & 0.03 & $<0.03$ & 0.04 & 0.03 & $<0.08$ & 0.1 \\
\hline $2,3,4,6,7,8-\mathrm{HxCDF}$ & 0.5 & 0.4 & 0.04 & $<0.03$ & $<0.02$ & 0.02 & $<0.08$ & 0.1 \\
\hline $1,2,3,7,8,9-\mathrm{HxCDF}$ & $<0.04$ & 0 & $<0.04$ & $<0.03$ & $<0.03$ & $<0.1$ & $<0.09$ & $<0.02$ \\
\hline $1,2,3,4,6,7,8-\mathrm{HpCDF}$ & 3.7 & 4.2 & 0.2 & 0.2 & 0.1 & 0.1 & 0.9 & 0.9 \\
\hline $1,2,3,4,7,8,9-\mathrm{HpCDF}$ & 0.4 & 0.3 & 0.04 & $<0.02$ & 0.04 & $<0.02$ & 0.1 & 0.1 \\
\hline OCDF & 18 & 15 & 0.6 & 0.5 & 1.8 & 3.2 & 3.4 & 7.4 \\
\hline $2,3,7,8-\mathrm{TCDD}$ & $<0.06$ & $<0.06$ & $<0.07$ & 0.2 & 0.1 & $<0.2$ & $<0.2$ & 0.05 \\
\hline $1,2,3,7,8-\mathrm{PeCDD}$ & $<0.06$ & 0.1 & 0.2 & $<0.06$ & 0.1 & 0.1 & $<0.1$ & $<0.04$ \\
\hline $1,2,3,4,7,8-\mathrm{HxCDD}$ & 0.1 & $<0.06$ & 0.2 & 0.1 & 0.1 & 0.1 & $<0.07$ & 0.1 \\
\hline $1,2,3,6,7,8-\mathrm{HxCDD}$ & 0.04 & $<0.06$ & $<0.04$ & $<0.06$ & $<0.06$ & 0.03 & $<0.07$ & $<0.04$ \\
\hline $1,2,3,7,8,9-\mathrm{HxCDD}$ & 0.1 & $<0.06$ & 0.1 & 0.03 & $<0.02$ & 0.1 & 0.2 & 0.04 \\
\hline $1,2,3,4,6,7,8-\mathrm{HpCDD}$ & 1.4 & 2.1 & 0.4 & 0.6 & 0.2 & 0.3 & 1.4 & 1.3 \\
\hline OCDD & 51 & 87 & 15 & 20 & 14 & 71 & 58 & 62 \\
\hline Total Tetra-Furans & 34 & 51 & 17.3 & 31.6 & 78.8 & 18.3 & 13.1 & 3.9 \\
\hline Total Tetra-Dioxins & 10 & 6.7 & 5.1 & 13.8 & 20.6 & 2.8 & 2.0 & 1.6 \\
\hline Total Penta-Furans & 17 & 54.9 & 4.8 & 23.9 & 53.9 & 13.1 & 14.9 & 3.0 \\
\hline Total Penta-Dioxins & 2.4 & 9.2 & 0.1 & 4.5 & 16.3 & 6.0 & 4.0 & 0.9 \\
\hline Total Hexa-Furans & 7.8 & 45.6 & 4.5 & 8.7 & 17.9 & 34.5 & 9.3 & 2.2 \\
\hline Total Hexa-Dioxins & 7.1 & 16.6 & 2.5 & 13.2 & 37.8 & 16.2 & 13 & 11.2 \\
\hline Total Hepta-Furans & 5.5 & 23 & 1.8 & 3.7 & 7.5 & 21.5 & 6.5 & 1.9 \\
\hline Total Hepta-Dioxins & 12 & 46.8 & 7.3 & 21.8 & 50.5 & 71.8 & 43.7 & 4.8 \\
\hline$\Sigma \mathrm{PCDD} / \mathrm{Fs}$ & 164.8 & 355.8 & 59 & 141.7 & 299.1 & 258.4 & 167.9 & 87.7 \\
\hline$\Sigma 2378-P C D D / F s$ & 76 & 110 & 17 & 22 & 17 & 75 & 64 & 72 \\
\hline WHO-TEQ ${ }^{\mathrm{a}}$ & 0.34 & 0.39 & 0.29 & 0.27 & 0.22 & 0.22 & 0.29 & 0.16 \\
\hline WHO-TEQ ${ }^{\mathrm{b}}$ & 0.35 & 0.37 & 0.31 & 0.28 & 0.24 & 0.26 & 0.29 & 0.17 \\
\hline WHO-TEQ ${ }^{c}$ & 0.41 & 0.41 & 0.36 & 0.33 & 0.25 & 0.36 & 0.49 & 0.20 \\
\hline I-TEQ & 0.42 & 0.44 & 0.21 & 0.28 & 0.19 & 0.25 & 0.31 & 0.21 \\
\hline
\end{tabular}

a Replacing the concentrations $t$ that were less than the LOD with zero (labeled WHO-TEQ ${ }^{\mathrm{a}}$ ).

b Replacing the concentrations that were less than the LOD with $1 / 2$ LOD (labeled WHO-TEQ ${ }^{\text {b) }}$.

c Replacing the concentrations that were less than the LOD with LOD (labeled WHO-TEQ ${ }^{c}$ ).

$\Sigma 2,3,7,8-\mathrm{PCDD} / \mathrm{F}$ concentrations in Chinese technical Na-PCP. OCDD has been found to contribute $74-97 \%$ of the $\Sigma 2,3,7,8$ $\mathrm{PCDD} / \mathrm{F}$ concentrations in sediments from Dongting Lake (Zheng et al., 1997), suggesting that Na-PCP was the major source of PCDD/Fs in Dongting Lake. OCDD and octachlorodibenzofuran (OCDF) contributed $91-99 \%$ of the $\Sigma 2,3,7,8-\mathrm{PCDD} / \mathrm{F}$ concentrations in the water samples we analyzed in this study, and the $\Sigma$ PCDD concentrations were higher than the $\Sigma$ PCDF concentrations in each of the water samples except for the samples from sites S2 and S5. The predominant PCDD/F homologs were OCDD and heptachlorop-dibenzodioxin (HpCDD), which together contributed $74-85 \%$ to the $\Sigma$ PCDD concentration in each of the water samples, except for the samples from sites S4 and S5 (in which OCDD and HPCDD contributed $57 \%$ and $46 \%$ of the $\Sigma$ PCDD concentrations, respectively). The predominant PCDF homologs were the tetrachlorodibenzofurans and pentachlorodibenzofurans. Similar PCDD/F homolog patterns have been found in other studies. For example, Liu et al. (2008) reported that OCDD was the predominant congener and that $\Sigma$ PCDD concentrations were higher than $\Sigma$ PCDF concentrations in water from the Xijiang River, China. OCDD, $\mathrm{HpCDD}$, and OCDF have been found to be the main PCDD/F homologs in sediments from the Yangtze and Yellow Rivers (Hui et al., 2009). The PCDD/F congener profiles found in sediments from the Haihe River, the Dagu Drainage River (Liu et al., 2007), and Taihu Lake (Zhang and Jiang, 2005) also agreed well with the results of this study.

International and World Health Organization toxic equivalency factors (I-TEFs and WHO-TEFs) (Kutz et al., 1990; Van den Berg et al., 1998) were used to calculate the international toxic equivalents (I-TEQs and WHO-TEQs) for each water sample, to normalize the PCDD/F concentrations and estimate the overall toxicity of the mixtures present. The I-TEQs were $0.19-0.44 \mathrm{pg} \mathrm{L}^{-1}$, with a mean of $0.26 \mathrm{pg} \mathrm{L}^{-1}$, and the WHO-TEQs were $0.17-0.37 \mathrm{pg} \mathrm{L}^{-1}$, with a mean of $0.28 \mathrm{pg} \mathrm{L}^{-1}$. The highest I-TEQ was found in the sample from site S2, in which the highest $\Sigma 2,3,7,8-\mathrm{PCDD} / \mathrm{F}$ concentration was found, and the lowest I-TEQ was found in the sample from site S5, in which the lowest $\Sigma 2,3,7,8-\mathrm{PCDD} / \mathrm{F}$ concentrations was found. OCDD, OCDF, 1,2,3,4,6,7,8-heptachlorodibenzofuran, and $1,2,3,4,6,7,8-\mathrm{HpCDD}$ were the most abundant congeners in the water samples, but the I-TEQs were dominated by the contributions from 2,3,7,8-tetrachloro-p-dibenzodioxin, 1,2,3,7,8-pentachloro-p-dibenzodioxin, 2,3,4,7,8-pentachlorodibenzofuran, and $1,2,3,4,7,8$-hexachlorodibenzofuran. It is interesting to note that the PCDD TEQs were found to be higher than the PCDF TEQs in sediment samples contaminated with Na-PCP, but, in this study, the PCDD TEQs were lower than the PCDF TEQs in the water samples from sites S1 and S2. The ratios between the PCDD TEQs and the PCDF TEQs were 2.1-17.2 (with a mean of 8.3) in the samples from the other sites, and 4.0 in commercial Na-PCP. Therefore, the results of this study are consistent with Na-PCP being the main source of PCDD/Fs in Dongting Lake.

All of eight water samples contained higher WHO-TEQs than the Canadian environmental quality guideline $\left(0.038 \mathrm{pg} \mathrm{L}^{-1}\right.$ WHO-TEQ in freshwater) and the US EPA water quality criterion, which is $0.014 \mathrm{pg} \mathrm{L}^{-1}$ WHO-TEQ (US Environmental Protection Agency, 1984). There are limited data with which to compare the $\mathrm{PCDD} / \mathrm{F}$ concentrations found in the Dongting Lake water samples. PCDD/F concentrations of $0.012-0.075 \mathrm{pg} \mathrm{L}^{-1}$ WHO- TEQ were 
found in the Xijiang River (Liu et al., 2007). Kakimoto et al. (2006) found PCDD/F WHO-TEQs of 0.039-3.6 $\mathrm{pg} \mathrm{L}^{-1}$ in water samples from Japanese coastal areas. The PCDD/F concentrations we found in the water samples from Dongting Lake were, therefore, relatively high compared with concentrations that have been found in other areas.

The PCDD/F concentrations found in fish from Dongting Lake are shown in Table 3. The geometric mean is shown when more than one sample was analyzed for a single species. The $\Sigma 2,3,7,8$ PCDD/F concentrations on a wet weight basis were very different in different fish species, the highest $\Sigma \mathrm{PCDD} / \mathrm{F}$ concentrations being found in bream (17.9 $\mathrm{pg} \mathrm{g}^{-1}$ wet weight [ww]) and yellow catfish (16.2 $\mathrm{pg} \mathrm{g}^{-1} \mathrm{ww}$ ), which were both much higher than the concentrations found in the other fish species. The lowest $\Sigma 2,3,7,8-\mathrm{PCDD} /$ Fs concentrations were found in mandarin fish $\left(2.2 \mathrm{pg} \mathrm{g}^{-1} \mathrm{ww}\right)$, pomfret (2.6 $\left.\mathrm{pg} \mathrm{g}^{-1} \mathrm{ww}\right)$, and catfish $\left(2.6 \mathrm{pg} \mathrm{g}^{-1} \mathrm{ww}\right)$, which each had significantly lower $\Sigma 2,3,7,8-\mathrm{PCDD} / \mathrm{F}$ concentrations than the other fish species. The $\Sigma \mathrm{PCDD} / \mathrm{Fs}$ concentrations in the fish were 10.1-638 $\mathrm{pg} \mathrm{g}^{-1} \mathrm{ww}$, and the lowest PCDD/F concentration found, in catfish, was much lower than the concentrations found in any other species of fish. The lipid contents of the fish samples were $0.7-21 \%$, and, calculated on a lipid weight (lw) basis, the highest $\Sigma 2,3,7,8-\mathrm{PCDD} / \mathrm{F}$ concentrations were found in yellow catfish $\left(622 \mathrm{pg} \mathrm{g}^{-1} \mathrm{lw}\right)$ and carp $\left(486 \mathrm{pg} \mathrm{g}^{-1} \mathrm{lw}\right)$.

\section{2. $P C D D / F s$ in fish}

The PCDDs were found at higher concentrations than the PCDFs, contributing $54-95 \%$ of the $\Sigma \mathrm{PCDD} / \mathrm{F}$ concentrations in the fish samples except for yellow catfish (shown in Fig. 2). The main congeners were OCDD, 1,2,3,4,6,7,8-HpCDD, 1,2,3,4,7,8-hexachlorodibenzo-p-dioxin, and 2,3,4,7,8-pentachlorodibenzofuran, which contributed $30-79 \%, 4-35 \%, 1.2-12 \%$, and $1.1-10 \%$ of the $\Sigma$ PCDD/F concentrations, respectively. Relatively high PCDD concentrations have also been found in sediment samples from Dongting Lake. The PCDD/F congener patterns were different in yellow catfish than in other species, with PCDFs contributing 59\% to the $\Sigma 2,3,7,8-\mathrm{PCDD} / \mathrm{F}$ concentrations and the OCDD concentration being relatively low.

The lipid content and PCDD/F concentrations in bream were relatively high compared with other species of fish. OCDD was the most abundant congener in bream, followed by $2,3,7,8$ tetrachlorodibenzofuran, 1,2,3,4,7,8-hexachlorodibenzo-p-dioxin, 2,3,4,7,8-pentachlorodibenzofuran, 1,2,3,4,6,7,8-HpCDD, and 1,2,3,4,7,8-hexachlorodibenzofuran. The ratio of the PCDD and PCDF concentrations in bream was 6.0. Relatively high ratio of the PCDD and PCDF concentrations were found in technical Na-PCP and sediment samples from Dongting Lake.

WHO-TEFs for fish were used to calculate WHO-TEQs for each $\mathrm{PCDD} / \mathrm{F}$ congener, and these were summed to indicate the toxic potential as the equivalent of 2,3,7,8-tetrachloro- $p$-dibenzodioxin. The compounds that were included in the WHO-TEQ calculations are shown in Table 3.

The PCDD/F WHO-TEQs were 0.10-0.92 ww (3.3-65.3 lw) $\mathrm{pg} \mathrm{g}^{-1}$ in different species of fish from dongting Lake. The PCDD/ $\mathrm{F}$ WHO-TEQs were highest in the piscivorous fish, bream (1.9 $\left.\mathrm{pg} \mathrm{g}^{-1} \mathrm{ww}\right)$ and yellow catfish $\left(1.7 \mathrm{pg} \mathrm{g}^{-1} \mathrm{ww}\right)$, which had much higher WHO-TEQs than carp $\left(0.21 \mathrm{pg} \mathrm{g}^{-1} \mathrm{ww}\right)$, pomfret $\left(0.20 \mathrm{pg} \mathrm{g}^{-1} \mathrm{ww}\right)$, mandarin fish $\left(0.11 \mathrm{pg} \mathrm{g}^{-1} \mathrm{ww}\right)$, and catfish $\left(0.10 \mathrm{pg} \mathrm{g}^{-1} \mathrm{ww}\right)$.

Table 3

PCDD/F concentrations ( $\mathrm{pg} \mathrm{g}^{-1} \mathrm{ww}$ ) in different species of fish.

\begin{tabular}{|c|c|c|c|c|c|c|}
\hline & Bream & Carp & Yellow catfish & Pomfret & Mandarin fish & Catfish \\
\hline & $n=3$ & $n=3$ & $n=4$ & $n=3$ & $n=2$ & $n=2$ \\
\hline Lipid content (\%) & 21 & 2.7 & 2.6 & 3.2 & 1.9 & 3 \\
\hline $2,3,7,8-\mathrm{TeCDF}$ & 2.91 & 0.46 & 0.46 & 0.02 & 0.02 & 0.01 \\
\hline 1,2,3,7,8-PeCDF & 1.05 & 0.04 & 0.6 & 0.05 & 0.04 & 0.01 \\
\hline $2,3,4,7,8-\mathrm{PeCDF}$ & 1.81 & 0.2 & 0.85 & 0.15 & 0.06 & 0.03 \\
\hline $1,2,3,4,7,8-\mathrm{HxCDF}$ & 1.39 & 0.1 & 2.85 & 0.03 & 0.04 & $<0.01$ \\
\hline $1,2,3,6,7,8-\mathrm{HxCDF}$ & 0.04 & 0.05 & 1.62 & 0.02 & 0.03 & 0.01 \\
\hline $2,3,4,6,7,8-\mathrm{HxCDF}$ & 0.25 & 0.07 & 0.2 & $<0.03$ & 0.02 & $<0.02$ \\
\hline $1,2,3,7,8,9-\mathrm{HxCDF}$ & 0.04 & 0.01 & 0.03 & $<0.06$ & $<0.08$ & $<0.02$ \\
\hline 1,2,3,4,6,7,8-HpCDF & 0.26 & 0.11 & 2.65 & 0.02 & 0.07 & 0.02 \\
\hline $1,2,3,4,7,8,9-\mathrm{HpCDF}$ & 0.05 & 0.01 & 0.04 & $<0.04$ & 0.03 & $<0.01$ \\
\hline OCDF & 0.3 & 0.11 & 0.16 & 0.03 & 0.04 & 0.05 \\
\hline 2,3,7,8-TeCDD & 0.08 & 0.02 & 0.14 & 0.07 & 0.02 & $<0.02$ \\
\hline 1,2,3,7,8-PeCDD & 0.5 & 0.03 & 0.48 & 0.05 & 0.03 & 0.05 \\
\hline $1,2,3,4,7,8-\mathrm{HxCDD}$ & 2.15 & 0.14 & 1.33 & 0.03 & 0.2 & 0.25 \\
\hline $1,2,3,6,7,8-\mathrm{HxCDD}$ & 0.03 & 0.04 & 0.66 & $<0.06$ & 0.01 & 0.05 \\
\hline $1,2,3,7,8,9-\mathrm{HxCDD}$ & 0.61 & 0.02 & 0.58 & 0.11 & 0.02 & 0.01 \\
\hline 1,2,3,4,6,7,8-HpCDD & 1.67 & 0.23 & 0.74 & 0.5 & 0.15 & 0.08 \\
\hline OCDD & 4.73 & 1.76 & 2.77 & 1.52 & 1.4 & 2.07 \\
\hline Totals Tetra-Furans & 16.92 & 14.07 & 37.35 & 143.52 & 21.44 & 2.07 \\
\hline Totals Tetra-Dioxins & 2.23 & 2.27 & 12.76 & 18.08 & 0.67 & 0.02 \\
\hline Totals Penta-Furans & 22.79 & 22.93 & 54.59 & 48.55 & 74.32 & 0.46 \\
\hline Totals Penta-Dioxins & 55.41 & 1.85 & 11.7 & 48.14 & 0.67 & 0.05 \\
\hline Totals Hexa-Furans & 8.66 & 6.39 & 16.78 & 4.92 & 0.06 & 0.62 \\
\hline Totals Hexa-Dioxins & 96.65 & 6.18 & 12.04 & 75.16 & 0.69 & 0.84 \\
\hline Totals Hepta-Furans & 42.9 & 3.44 & 5.52 & 1.15 & 0.07 & 0.6 \\
\hline Totals Hepta-Dioxins & 387.85 & 26.48 & 8.46 & 4.47 & 7.46 & 3.33 \\
\hline$\Sigma 2,3,7,8-\mathrm{PCDD} / \mathrm{Fs}$ & 17.9 & 3.4 & 16.2 & 2.6 & 2.2 & 2.6 \\
\hline$\Sigma \mathrm{PCDD} / \mathrm{Fs}$ & 638 & 85 & 162 & 345 & 107 & 10.11 \\
\hline WHO-TEQ (FW) & 1.92 & 0.21 & 1.7 & 0.20 & 0.11 & 0.10 \\
\hline WHO-TEQ (FW) ${ }^{\mathrm{b}}$ & 1.92 & 0.21 & 1.7 & 0.20 & 0.11 & 0.10 \\
\hline WHO-TEQ (FW) ${ }^{\mathrm{c}}$ & 1.92 & 0.21 & 1.7 & 0.21 & 0.11 & 0.11 \\
\hline WHO-TEQ (IW) & 9.1 & 7.8 & 65.3 & 6.2 & 5.8 & 3.3 \\
\hline
\end{tabular}

\footnotetext{
a Replacing the concentrations that were less than the LOD with zero (labeled WHO-TEQ ${ }^{\mathrm{a}}$ ).

b Replacing the concentrations that were less than the LOD with 1/2 LOD (labeled WHO-TEQ ${ }^{\mathrm{b}}$ ).

c Replacing the concentrations that were less than the LOD with the LOD (labeled WHO-TEQ ${ }^{\mathrm{C}}$.
} 


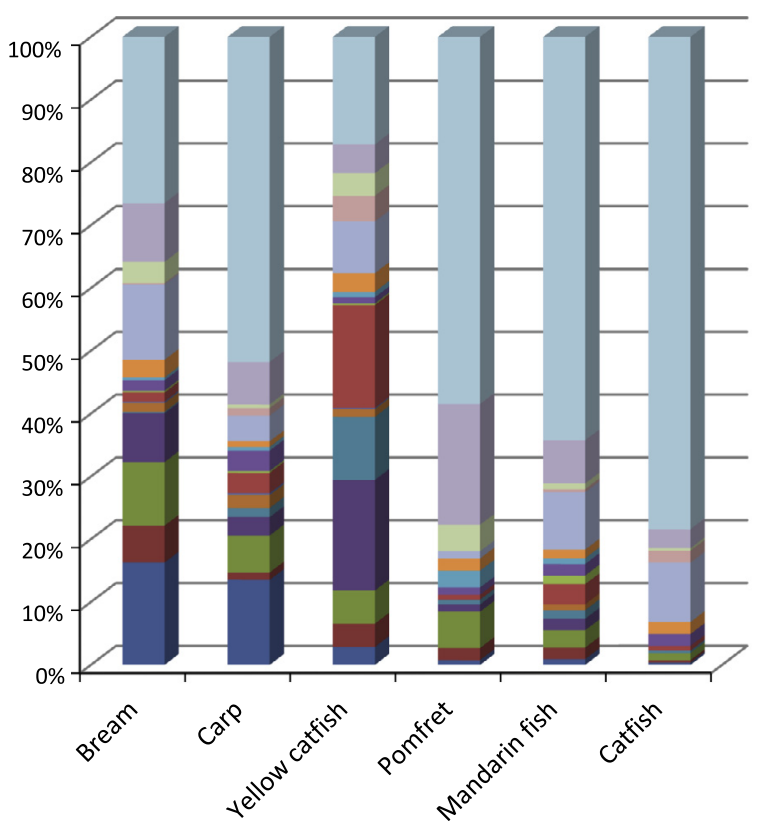

OCDD

1,2,3,4,6,7,8-HpCDD

$=1,2,3,7,8,9-\mathrm{HxCDD}$

$1,2,3,6,7,8-\mathrm{HxCDD}$

$1,2,3,4,7,8-\mathrm{HxCDD}$

$1,2,3,7,8-\mathrm{PeCDD}$

2,3,7,8-TeCDD

- OCDF

$=1,2,3,4,7,8,9-\mathrm{HpCDF}$

-1,2,3,4,6,7,8-HpCDF

- $1,2,3,7,8,9-\mathrm{HxCDF}$

$=2,3,4,6,7,8-\mathrm{HxCDF}$

$=1,2,3,6,7,8-\mathrm{HxCDF}$

$1,2,3,4,7,8-\mathrm{HxCDF}$

- $2,3,4,7,8-\mathrm{PeCDF}$

1,2,3,7,8-PeCDF

$=2,3,7,8-\mathrm{TeCDF}$

Fig. 2. Polychlorinated dibenzo-p-dioxin and dibenzofuran congener profiles in the fish species analyzed.

The lipid-based PCDD/F WHO-TEQs were also higher in piscivorous fish than in the other fish, the highest PCDD/F WHO-TEQ being found in yellow catfish (65.3 $\mathrm{pg} \mathrm{g}^{-1} \mathrm{lw}$ ) and the lowest being found in catfish (3.3 $\mathrm{pg} \mathrm{g}^{-1} \mathrm{lw}$ ). 1,2,3,4,7,8-Hexachloro-p-dibenzodioxin, 2,3,4,7,8-pentachlorodibenzofuran, and 1,2,3,7,8-pentachloro- $p$-dibenzodioxin were the predominant contributors to the WHO-TEQs. Higher 2,3,7,8-tetrachloro-p-dibenzodioxin concentrations were found in carp and pomfret than in the other species, and this congener was a strong contributor to the WHO-TEQs for these species. The PCDD/F WHO-TEQs did not exceed the European Union food guidelines in any of the fish samples. The PCDD/F WHO-TEQs were in the same magnitude with the fish samples that have been found in other fish species taken from the other sites. PCDD/F WHO-TEQs of $0.48-9.05 \mathrm{pg} \mathrm{g}^{-1} \mathrm{ww}$ were found in marine fish from near Hong Kong and in the Pearl River Delta, China (Wei et al., 2011), and PCDD/F and ('dioxin-like') PCB WHO-TEQs of $0.05-8.0 \mathrm{pg} \mathrm{g}^{-1} \mathrm{ww}$ were found in freshwater fish and eels from Latvian lakes (Zacs et al., 2013).

\subsection{Bioaccumulation}

The 2,3,7,8-PCDD/F concentrations on a wet weight basis were very different in different fish species. The equilibrium partitioning theory is the best known and most used model for predicting the body burdens of contaminants in aquatic organisms. It is assumed, in this theory, that the concentration of a chemical in an organism is solely determined by the concentration in the water phase and the organism's lipid content (Van der Kooij et al., 1991). The lipid content was significantly higher in bream than in other species, and the PCDD/F concentrations on a wet weight basis were higher in bream than in other fish, partly because of their high lipid contents. However, the PCDD/F concentrations in the different fish species were not equal on a lipid basis. The bioaccumulation of extremely hydrophobic compounds cannot be explained satisfactorily by simple partitioning between sediment, water, and fish.

The PCDD/PCDF concentration ratios were 0.11-1.77, 5.57-6.52, and $0.15-1.59$ in the piscivorous, omnivorous, and graminivorous fish, respectively. These ratios were much higher in some fish species than in sediment samples, indicating that some fish bioaccumulated PCDFs more than PCDDs. The PCDF concentrations were also higher than the PCDD concentrations in fish from Ya-er Lake, China, that had been exposed to the pollutants hexachlorocyclohexane, hexachlorobenzene, and pentachlorophenol (Wu et al., 2001). In that study, the PCDD/F concentrations were lower in the fish and shrimp than in the piscivorous fish that fed on them and in the sediments. The PCDD/PCDF concentration ratios being much higher in some fish species than in the sediment samples may, therefore, be the reason why the PCDD/Fs concentrations were not higher in the piscivorous fish than in the omnivorous and graminivorous fish.

The bioconcentration factors (BCFs) between the water and the fish in this study were calculated using the average PCDD/F concentrations in the water samples, using the equation

$\mathrm{BCF}=\frac{C_{\mathrm{f}}}{C_{\mathrm{w}} \rho_{\mathrm{w}}}$

where $C_{\mathrm{f}}$ is the PCDD/F concentration in the fish, $C_{\mathrm{w}}$ is the PCDD/F concentration in the water, and $\rho_{\mathrm{w}}$ is the density of water $\left(1000 \mathrm{~g} \mathrm{~L}^{-1}\right)$. The congener specific BCFs ranged between 2.56 and 59692. The highest and lowest BCFs were found in the Pelteobagrus fulvidraco (yellow catfish) and the Silurus asotus (catfish), respectively. Fig 3 shows that the BCFs for the 2,3,7,8-PCDD/Fs statistically significantly correlated with the Kow values for the six fish species that were sampled. It appears that 2,3,7,8-TCDD is absorbed and eliminated at constant rates by the fish because of its physicalchemical properties. OCDD and OCDF are absorbed at extremely low rates because membrane permeation of chemicals with relatively high molecular weights, such as these, within the fish is inhibited. Hydrophobic compounds with high log Kow values are also less effectively bioaccumulated than those compounds with lower log Kow values, because the former tend to partition strongly to sediments, making them less bioavailable to organisms (Loonen et al., 1994). Our results agree with the results of previous studies, which have shown that the bioaccumulation of PCDD/F congeners cannot solely be explained by their physical-chemical properties. 


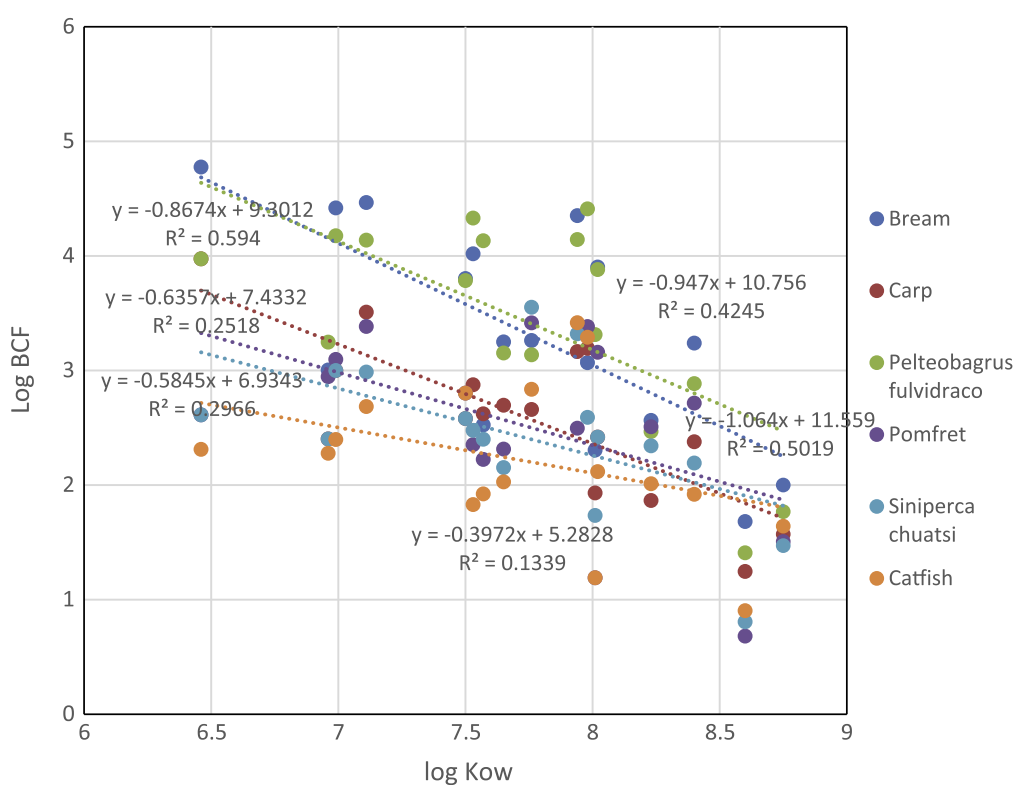

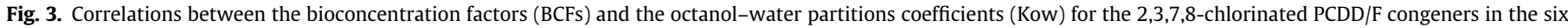
fish species that were analyzed.

The accumulation of PCDD/Fs in fish may be affected by food chain biomagnification and the lipid content of the species of interest.

\section{Conclusions}

Dongting Lake is the second largest freshwater lake in China, and is contaminated with PCDD/Fs because of Na-PCP being used between the 1960s and the 1980s. The PCDD/F concentrations in eight water samples, distributed around Dongting Lake, were $36-345 \mathrm{pg} \mathrm{L}^{-1}$, and the mean was $191 \mathrm{pg} \mathrm{L}^{-1}$. The $\Sigma \mathrm{PCDD} / \mathrm{F}$ concentrations in the water samples agreed with the $\Sigma P C D D / F$ concentrations in sediment samples. OCDD was the predominant $\mathrm{PCDD} / \mathrm{F}$ congener in the water at every site, contributing $67-95 \%$ of the $\Sigma 2,3,7,8-\mathrm{PCDD} / \mathrm{F}$ concentrations. The PCDD/F concentrations in Dongting Lake water samples were somewhat higher than concentrations that have been reported in other studies.

The 2,3,7,8-PCDD/F concentrations, on a wet weight basis, were very different in the different fish species analyzed, ranging from 10.1 to $638 \mathrm{pg} \mathrm{g}^{-1} \mathrm{ww}$. The PCDDs were found at higher concentrations than the PCDFs in each species, contributing $54-95 \%$ of the $\Sigma \mathrm{PCDD} / \mathrm{F}$ concentrations, except for in yellow catfish. The PCDD/F WHO-TEQs were 0.10-0.92 ww (3.3-65.3 lw) $\mathrm{pg} \mathrm{g}^{-1}$ in different species of fish. The PCDD/F concentrations did not exceed the European Union food guidelines in any of the fish species. The bioaccumulation of extremely hydrophobic compounds cannot be explained satisfactorily by simple partitioning between the sediment, water, and fish. The PCDD/F homolog patterns were different in different fish species. The congener specific bioconcentration factors (BCFs) ranged between 2.56 and 59692 in different species of fish. PCDD/Fs with high log Kow values are less effectively bioaccumulated than those with lower log Kow values. The bioaccumulation of PCDD/F congeners cannot solely be explained by their physical-chemical properties.

\section{Acknowledgments}

This study was financially supported by the Main Direction Program of Knowledge Innovation of Chinese Academy of Sciences, China (Grant No. KZXZ-YW-JS406) and the National Natural Science Foundation of China (Grant No. 21377140, 21321004).

\section{References}

Bao, Z.C., Wang, K.O., Kang, J.X., Zhao, L.W., 1995. Analysis of polychlorinated dibenzo-p-dioxins and polychlorinated dibenzofurans in pentachlorophenol and sodium pentachlorophenate. Environ. Chem. 14, 317-321 (in Chinese).

Gao, L., Zheng, M., Zhang, B., Zhao, X., 2008. Declining Polychlorinated Dibenzo-pdioxins and Dibenzofurans levels in sediments from Dongting Lake in China. Chemosphere 73, S176-S179.

Hui, Y., Zheng, M., Liu, Z., Gao, L., 2009. PCDD/Fs and dioxin-like PCBs in sediments from Yellow Estuary and Yangtze Estuary, China. Bull. Enviro.n Contam. Toxicol. 83 (4), 614-619.

Im, S.H., Strause, K.D., Giesy, J.P., Chang, Y.S., Matsuda, M., Wakimoto, T., 2004 Concentrations and accumulation profiles of polychlorinated dibenzo-p-dioxins and dibenzofurans in aquatic tissues, and ambien air from South Korea. Chemosphere 55 (10), 1293-1302.

Ishaq, R., Persson, N.J., Zebühr, Y., Broman, D., Næs, K., 2009. PCNs, PCDD/Fs, and Non-orthoPCBs, in Water and Bottom Sediments from the Industrialized Norwegian Grenlandsfjords. Environ Sci Techno 43, 3442-3447.

Josefsson, S., Schaanning, M., Samuelsson, G.S., Gunnarsson, J.S., Id, Olofsson., Eek, E., Wiberg, K., 2012. Capping efficiency of various carbonaceous and mineral materials for in situ remediation of polychlorinated dibenzo-p-dioxin and dibenzofuran contaminated marine sediments: sediment-to-water fluxes and bioaccumulation in boxcosm tests. Environ. Sci. Technol. 46 (6), 3343-3351.

Kakimoto, H., Oka, H., Miyata, Y., Yonezawa, Y., Niikawa, A., Kyudo, H., Tang, N., Toriba, A., Kizu, R., Hayakawa, K., 2006. Homologue and isomer distribution of dioxins observed in water samples collected from Kahokugata Lagoon and inflowing rivers, Japan. Water. Res. 40 (10), 1929-1940.

Kumar, K.S., Kannan, K., Paramasivan, O.N., Nakanishi, Sundaram V.P.S., Masunaga, S., 2001. Polychlorinated Dibenzo-p-Dioxins, Dibenzofurans, and Polychlorinated Biphenyls in Human Tissues, Meat, Fish, and Wildlife Samples from India. Environ. Sci. Technol. 35 (17), 3448-3455.

Kutz, F.W., Barnes, D.G., Bottimore, D.P., Greim, H., Bretthauer, E.W., 1990. The international toxicity equivalency factor (I-TEF) method of risk assessment for complex mixtures of dioxins and related compounds. Chemosphere 20, 751757.

Li, Y., Liu, F., Zhang, C., 2011. Environmental trends and causes of wetland water from Dongting lake, China. J. Ecol. Environ. Sci. 20 (8-9), 1295-1300 (in Chinese).

Liu, H., Zhang, Q., Wang, Y., Cai, Z., Jiang, G., 2007. Occurrence of polychlorinated dibenzo- p-dioxins, dibenzofurans and biphenyls pollution in sediments from the Haihe River and Dagu Drainage River in Tianjin City, China. Chemosphere 68 (9), 1772-1778.

Liu, Y., Peng, P., Li, X., Zhang, S., Ren, M., 2008. Polychlorinated dibenzo- p-dioxins and dibenzofurans (PCDD/Fs) in water and suspended particulate matter from the Xijiang River, China. J. Hazard. Mater. 152 (1), 40-47.

Loonen, H., Parsons, J.R., Govers, H.A.J., 1994. Effect of sediment on the bioaccumulation of a complex mixture of polychlorinated dibenzo-pdioxins(PCDDs) and polychlorinated dibenzofurans (PCDFs) by fish. Chemosphere 28, 1433-1446.

Ren, M., Peng, P., Chen, D., Chen, P., Li, X., 2009. Patterns and sources of PCDD/Fs and dioxin-like PCBs in surface sediments from the East River, China. J. Hazard. Mater. 170, 473-478. 
US EPA February, 1984. Ambient water quality criteria for 2,3,7,8-Tetrachlorodibenzo-p-dioxin. EPA 440/5-84-007.

Van der Kooij, L.A., van de Meent, D., van Leeuwen, C.J., Bruggeman, W.A., 1991. Deriving quality criteria for water and sediment from aquatic toxicity tests and product standards: application of the equilibrium partitioning method. Water. Res. 25, 697-705.

Van den Berg, M., Birnbaum, L., Bosveld, A., Brunström, B., Cook, P., Feeley, M., Giesy, J.P. Hanberg, A., Hasegawa, R., Kennedy, S.W., 1998. Toxic equivalency factors (TEFs) for PCBs, PCDDs, PCDFs for humans and wildlife. Environ health persp 106, 775.

Wei, X., Leung, K.S., Wong, M.H., Giesy, J., Cai, Z.W., Wonga Chris, K.C., 2011. Assessment of risk of PCDD/Fs and dioxin-like PCBs in marine and freshwater fish in Pearl River Delta, China. Mar. Pollut. Bull. 63, 166-171.

Wu, W.Z., Schramm, K.W., Kettrup, A., 2001. Bioaccumulation of polychlorinated dibenzo-p-dioxins and dibenzofurans in the foodweb of Ya-Er Lake area, China. Water Res. 35, 1141-1148.
Yeager, K.M., Santschi, P.H., Rifai, H.S., Suarez, M.P., Brinkmeyer, R., Hung, C.-C., Schindler, K.J., Andres, M.J., Weaver, E.A., 2007. Dioxin chronology and fluxes in sediments of the houston ship channel, texas: influences of non-steady-state sediment transport and total organic carbon. Environ. Sci. Technol. 41 (15), 5291-5298.

Zacs, D., Bartkevics, V., Viksna, A., 2013. Content of polychlorinated dibenzo-pdioxins, dibenzofurans and dioxin-like polychlorinated biphenyls in fish from Latvian lakes. Chemosphere 91, 179-186.

Zhang, Q., Jiang, G., 2005. Polychlorinated dibenzo-p-dioxins/furans and polychlorinated biphenyls in sediments and aquatic organisms from the Taihu Lake, China. Chemosphere 61 (3), 314-322.

Zheng, M., Bao, Z, Yang $\mathrm{H}$., Xu, X, 1997. Polychlorinated dibenzo-p-dioxins and dibenzofurans in lake sediments from Chinese schistosomiasis areas. Bull. Environ. Contam. Toxicol. 59, 653-656. 